Jurnal Mandala Pharmacon Indonesia, Vol 6.No.1 Juni 2020

Avaiable online at www.jurnal-pharmaconmw.com/jmpi

p-ISSN : 2442-6032

$e$-ISSN : 2598-9979

\title{
Formulasi Dan Uji Aktivitas Sediaan Sabun Cair Pembersih Kewanitaan Ekstrak Daun Waru (Hibiscus tiliaceus) Terhadap Jamur Candida albicans
}

Nikeherpianti Lolok, Nurhatidjah Awaliyah, Windi Astuti

Program Studi Farmasi, STIKES Mandala Waluya, Kendari

\begin{abstract}
ABSTRAK
Keputihan merupakan salah satu dari gejala gangguan organ reproduksi yang disebabkan oleh jamur yang ditandai dengan keluarnya cairan berlebih dari vagina sehingga menimbulkan bau yang tidak sedap yang biasanya dialami oleh wanita. Daun waru (Hibiscus tiliaceus) merupakan salah satu tanaman yang berpotensi sebagai antijamur. Tujuan dari penelitian ini adalah untuk mengetahui stabilitas fisik sediaan sabun cair pembersih kewanitaan ekstrak daun waru serta untuk mengetahui konsentrasi paling baik dalam menghambat aktivitaas terhadap jamur Candida albicans. Penelitian dilakukan secara laboratorium eksperimental, sampel diekstraksi dengan metode maserasi menggunakan pelarut etanol 96\% dan

One-Way ANNOVA. Hasil penelitian menunjukkan bahwa ekstrak daun waru positif mengandung senyawa flavanoid, saponin, triterpenoid dan sterol, tanin dan polifenol. Ekstrak dalam formulasi sediaan sabun cair pembersih kewanitaan ekstrak daun waru memenuhi syarat evaluasi fisik dimana sabun cair pembersih kewanitaan tersebut tetap berwarna hijau pekat, bau khas mawar serta bentuknya cair. Sabun cair pembersih kewanitaan ekstrak daun waru dengan konsentrasi 5\% memiliki daya hambat sebesar 21,10 mm, konsentrasi 10\% sebesar 21,77 mm dan konsentrasi $15 \%$ sebesar 20,55 mm terhadap jamur Candida albicans dengan diperoleh hasil analisis anova yang signifikan $\mathrm{o}, \mathrm{O} 1(\mathrm{p}<0,05)$.
\end{abstract} diperoleh ekstrak kental sebanyak 99,94 gram. Ekstrak kental digunakan sebagai antijamur dalam pembuatan sabun cair pembersih kewanitaan pada konsentrasi ekstrak 5\%, 10\%, dan 15\%. Selanjutnya dilakukan skrining fitokimia, formulasi sediaan serta evaluasi fisik sediaan meliputi uji organoleptik, pH, homogenitas, tinggi busa dan uji iritasi. Selanjutnya uji aktivitas antijamur dilakukan dengan menggunakan metode cakram disk. Analisis data dilakukan dengan menggunakan
Kata Kunci: Sabun cair pembersih kewanitaan, ekstrak daun waru (Hibiscus tiliaceus), Antijamur, Candida albicans

Penulis Korespondensi :

Nikeherpianti Lolok

Program Studi Farmasi, STIKES Mandala

Waluya, Kendari

E-mail : nikeherpianti.apt@gmail.com

\section{PENDAHULUAN}

Kesehatan organ reproduksi sangatlah penting untuk diperhatikan, dimana organ reproduksi misalnya pada wanita seperti vagina merupakan daerah yang penting untuk dirawat dan butuh perhatian khusus karena letaknya yang tertutup. 
Keputihan atau dikenal dengan istilah medisnya Flour Albus, adalah cairan yang berlebihan yang keluar dari vagina. Cairan keputihan yang normal itu berwarna putih jernih, bila menempel pada pakaian dalam akan berwarna kuning terang konsistensi seperti lender, encer atau kental tergantung siklus hormon, tidak berbau dan tidak menimbulkan keluhan (Indah, 2011).

Prevalensi masalah kesehatan refroduksi di Indonesia semakin meningkat. Berdasarkan hasil penelitian menyebutkan bahwa tahun 2010, 52\% wanita di Indonesia mengalami keputihan, kemudian pada tahun 2011, 60\% wanita pernah mengalami keputihan, sedangkan tahun 2012 hampir 70\% wanita di Indonesia pernah mengalami keputihan, dan pada tahun 2013 bulan januari hingga agustus hampir 55\% wanita pernah mengalami keputihan. Kasus flour albus di Sulawesi Tenggara pada tahun 2010 mencapai 37 kasus dengan prevalensi 33.8 per 1.000 .000 penduduk wanita. Terjadi peningkatan kasus flour albus pada tahun 2011, mencapai 90 kasus dengan prevalensi 80.5 per 1.00o.0oo penduduk wanita. Terjadi penurunan kasus kasus flour pada tahun 2012 mencapai 54 kasus dengan prevalensi 49.6 per 1.000 .000 penduduk wanita di Kota Kendari (Darma,dkk 2017) dan sekitar 85-95\% keputihan disebabkan oleh jamur Candida albicans (Handayani, dkk 2017).

Penanganan dari keputihan yang disebabkan oleh Candida albicans dapat berupa perilaku sehat dalam menjaga kebersihan alat kelamin, Menjaga kebersihan pakaian dalam, dan mencuci tangan sebelum mencuci alat kelamin serta penggunaan obatobat kimia (Marhaeni, 2016). Obatobat keputihan diantaranya adalah Flusitosin, Ketokenazol, Flukonazol, Posakonazol, dan Ekinokandin fluconazole yang merupakan beberapa pilihan pengobatan antifungal Candida albicans (Katzung, 2013). Penggunaan antijamur yang tidak sesuai dengan aturannya sering menjadi penyebab terjadinya resistensi jamur (Elin dkk, 2008), sehingga hal inilah yang memicu untuk mencari agen-agen pengobatan yang baru yang lebih efektif dalam menghambat aktivitas jamur dan memiliki efek samping yang lebih rendah salah satu upaya yang dilakukan ialah dengan penggunaan bahan tradisional karena dinilai memiliki efek samping yang lebih kecil dibandingkan dengan yang berasal dari bahan kimia dan harganya yang relatif terjangkau (Putri, 2010). 
Salah satu tanaman obat tradisional yang banyak dimanfaatkan di Indonesia adalah daun waru (Hibiscus tiliaceus L.) dimana daun waru mengandung senyawa saponin, flavanoid, polifenol dan triterpenoid yang dapat berkasiat sebagai antifungi (Saleh, dkk.,2020) dan berdasarkan penelitian yang dilakukan kusuma (2009) tanaman waru yang memiliki khasiat antifungi ialah pada bagian batangnya dimana pada konsentrasi 15,8\% berefek sebagai antifungi dan kandungan pada batang tanaman waru ialah alkaloid, triterpenoid, flavanoid dan karbohidrat dan pada daun tanaman waru pada konsentrasi 5\% sampai 20\% menunjukkan efek antibakteri yang terus meningkat, kandungan yang terdapat pada daun tanaman waru ialah saponin, steroid, tanin, polifenol, dan flavanoid (Lusiana,dkk 2013).

Untuk menjaga sistem organ kewanitaan biasanya wanita menggunakan cairan pembersih untuk membersihkannya dan umumnya pada masyarakat didaerah perkotaan lebih menyukai hal-hal yang praktis sehingga sediaan sabun cair dipilih, karena lebih mudah digunakan juga lebih higienis. Berdasarkan hal tersebut, maka perlu dilakukan pengujian tentang potensi sediaan sabun cair pembersih kewanitaan (Feminime Hygiene) ekstrak daun waru terhadap jamur candida albicans sebagai antifungi dan sebagai bukti ilmiah. Penelitian ini dapat menjadi upaya untuk mengatasi masalah keputihan dan meminimalkan penggunaan obat-obat kimia dan memperkecil efek samping yang ditimbulkan akibat penggunaan obat kimia.

\section{METODE PENELITIAN}

Adapun tujuan dari penelitian ini yaitu untuk mengetahui stabilitas fisik sediaan sabun cair pembersih kewanitaan (Feminime Hygiene) dari ekstrak daun waru (Hibiscus tiliaceus) serta untuk mengetahui konsentrasi efektif sediaan sabun cair pembersih kewanitaan (Feminime Hygiene) dari ekstrak daun waru (Hibiscus tiliaceus) memiliki aktivitas antifungi terhadap Candida albicans.

\section{A. Alat Penelitian}

Adapun alat-alat yang digunakan dalam penelitian ini yaitu, autoklaf (Mammert), batang pengaduk, cawan porselin, cawan petri, gelas kimia (pyrex), erlenmeyer, batang pengaduk, gelas ukur (pyrex), hot plate, inkubator (yenaco), jangka sorong, jarum ose, kertas saring, kapas, lumpang dan alu, lakban hitam, pH meter, pingset, pipet ukur pyrex $10 \mathrm{ml}$, pipet ukur (pyrex), pipet tetes (pyrex) 1 
$\mathrm{ml}$, cakramdisk, rotavapor, tabung reaksi (pyrex), rak tabung, timbangan analitik, timbangan digital, water bath, wadah maserasi, laminar air flow (Cryste), lampu spiritus dan oven (yenaco), vakum, dan rotavapor.

\section{B. Bahan Penelitian}

Bahan-bahan yang digunakan dalam penelitian ini yaitu, daun waru, Propilen glikol (Dow), Setil alkohol (Lansida), Adeps lanae (Dwilabmandiri), Cera flava (Dwilabmandiri), Asam sitrat (Emprove), Oleum rosae (Dwilabmandiri), Aquadest (Maxlab), Media PDA (Potato Dekstrosa Agar), DMSO, dan Etanol 96\%.

\section{Prosedur Kerja}

\section{Pengambilan Sampel}

Sampel diperoleh dari Desa Lalonggowuna Kec. Tongauna Kab. Konawe.

2. Determinasi Sampel

Determinasi sampel dilakukan di Laboratorium Biologi Fakultas FKIP Universitas Halu Oleo dengan nomor surat 30/BIO/PL/IV/2019.

3. Pengolahan Sampel

Sampel yang digunakan adalah daun waru. Daun waru yang telah dipetik kemudian disortasi kering dipisahkan daun dari batang, setelah daun dipisahkan dari batangnya kemudian dilakukan sortasi basah.
Setelah itu sampel ditiriskan untuk mengurangi kandungan air pada saat sortasi basah, kemudian dilakukan perajangan, daun waru yang telah dirajang kemudian diangin-anginkan hingga kering lalu ditimbang.

4. Ekstraksi

Dilakukan proses ekstraksi dengan menggunakan metode maserasi. Adapun sampel daun waru yang digunakan sebanyak 832,88 g kemudian ditambahkan pelarut etanol 96\% sebanyak $6.246 \mathrm{~mL}$ hingga sampel terendam atau selapis di atas permukaan sampel. Wadah ditutup toples dengan lakban hitam yang sebelumnya dilapisi dengan almunium foil, kemudian wadah disimpan disimpan selama 3 hari pada suhu kamar, terlindung dari cahaya. Dengan perlakuan tiap hari diaduk sebanyak 3 kali sehari yakni pagi, siang dan sore hingga pada hari ke-3. Kemudian maserat yang diperoleh disaring kemudian dikumpulkan, lalu dipekatkan dalam rotary evaprator $\left(65^{\circ} \mathrm{C}, 60 \mathrm{rpm}\right)$ hingga menghasilkan ekstrak kental .

5. Skrining Kandungan Kimia

a . Pemeriksaan Alkaloid

Larutan ekstrak uji sebanyak $2 \mathrm{~mL}$ diuapkan di atas cawan porselin hingga di dapat residu. Residu kemudian dilarutkan 
dengan $5 \mathrm{~mL} \mathrm{HCl} 2 \mathrm{~N}$. Larutan yang didapat kemudian dibagi ke dalam 3 tabung reaksi. Tabung pertama ditambahkan dengan $\mathrm{HCl} 2 \mathrm{~N}$ yang berfungsi sebagai blanko. Tabung kedua ditambahkan Pereaksi Dragendorff sebanyak 3 tetes dan tabung ketiga ditambahkan Pereaksi Mayer sebanyak 3 tetes. Terbentuknya endapan jingga pada tabung kedua dan endapan putih hingga kekuningan pada tabung ketiga menunjukkan adanya alkaloid (Idadi,2013).

b. Pemeriksaan Sterol dan Triterpenoid

Ekstrak dilarutkan dalam 0,5 mL kloroform, lalu ditambah dengan 0,5 $\mathrm{mL}$ asam asetat anhidrat. Selanjutnya, campuran ini ditetesi dengan $2 \mathrm{~mL}$ asam sulfat pekat melalui dinding tabung tersebut. Bila terbentuk warna hijau kebiruan menunjukkan adanya sterol. Jika hasil yang diperoleh berupa cincin kecokelatan atau violet pada perbatasan dua pelarut, menunjukkan adanya triterpenoid (Idadi, 2013). c. Tanin dan Polifenol

Larutan ekstrak uji sebanyak $1 \mathrm{~mL}$ direaksikan dengan larutan besi (III) klorida 10\%, jika terjadi warna biru tua, biru kehitaman atau hitam kehijauan menunjukkan adanya senyawa polifenol dan tanin.

d. Pemeriksaan Saponin

Ekstrak uji dimasukkan ke dalam tabung reaksi, ditambahkan $10 \mathrm{~mL}$ air panas, dinginkan dan kemudian dikocok kuat-kuat selama 10 detik. Terbentuk buih yang mantap selama tidak kurang dari 10 menit setinggi 1-10 cm. Pada penambahan $\mathrm{HCl} 2 \mathrm{~N}$, buih tidak hilang.

e. Pemeriksaan Flavonoid

Larutan ekstrak uji sebanyak $1 \mathrm{ml}$ diuapkan hingga kering, sisanya dibasahkan dengan aseton $\mathrm{P}$, ditambahkan sedikit serbuk halus asam borat $\mathrm{P}$ dan serbuk halus asam oksalat $P$, dipanaskan hati-hati di atas penangas air dan dihindari pemanasan berlebihan. Sisa yang diperoleh dicampur dengan 10 $\mathrm{mL}$ eter $\mathrm{P}$, dan kemudian diamati dengan sinar UV $366 \mathrm{~nm}$; larutan berfluorosensi kuning intensif, menunjukkan adanya flavonoid. 
6. Formula

\begin{tabular}{|c|c|c|c|c|c|}
\hline \multirow[t]{2}{*}{ Bahan } & \multicolumn{4}{|c|}{ Formula } & \multirow[b]{2}{*}{$\begin{array}{l}\text { Kegu } \\
\text { naan }\end{array}$} \\
\hline & $\begin{array}{c}\text { A } \\
(\% \\
)\end{array}$ & $\begin{array}{c}\text { B } \\
(\% \\
)\end{array}$ & $\begin{array}{c}\text { C } \\
(\% \\
)\end{array}$ & $\begin{array}{c}\begin{array}{c}\text { Kontr } \\
\text { ol } \\
\text { negat } \\
\text { if }\end{array} \\
\text {. }\end{array}$ & \\
\hline $\begin{array}{c}\text { Ekstrak } \\
\text { Daun } \\
\text { Waru }\end{array}$ & $5 \%$ & $\begin{array}{l}10 \\
\%\end{array}$ & $\begin{array}{l}15 \\
\%\end{array}$ & - & $\begin{array}{c}\text { Zat } \\
\text { Aktif }\end{array}$ \\
\hline $\begin{array}{c}\mathrm{Na} \\
\text { Lauril } \\
\text { Sulfat }\end{array}$ & $\begin{array}{l}10 \\
\%\end{array}$ & $\begin{array}{l}10 \\
\%\end{array}$ & $\begin{array}{l}10 \\
\%\end{array}$ & $10 \%$ & $\begin{array}{c}\text { Emulg } \\
\text { ator }\end{array}$ \\
\hline $\begin{array}{c}\text { Propilen } \\
\text { glikol }\end{array}$ & $4 \%$ & $4 \%$ & $4 \%$ & $4 \%$ & $\begin{array}{l}\text { Pelem } \\
\text { but } \\
\text { dan } \\
\text { pelem } \\
\text { bab }\end{array}$ \\
\hline $\begin{array}{c}\text { Setil } \\
\text { alKohol }\end{array}$ & $2 \%$ & $2 \%$ & $2 \%$ & $2 \%$ & $\begin{array}{c}\text { Pembe } \\
\text { ntuk } \\
\text { sabun }\end{array}$ \\
\hline $\begin{array}{l}\text { Adeps } \\
\text { lanae }\end{array}$ & $2 \%$ & $2 \%$ & $2 \%$ & $2 \%$ & $\begin{array}{c}\text { Pembe } \\
\text { ntuk } \\
\text { sabun }\end{array}$ \\
\hline $\begin{array}{l}\text { Cera } \\
\text { flava }\end{array}$ & $2 \%$ & $2 \%$ & $2 \%$ & $2 \%$ & $\begin{array}{c}\text { Pembe } \\
\text { ntuk } \\
\text { sabun }\end{array}$ \\
\hline $\begin{array}{l}\text { Asam } \\
\text { sitrat }\end{array}$ & $\begin{array}{l}0,2 \\
5 \%\end{array}$ & $\begin{array}{l}0.2 \\
5 \%\end{array}$ & $\begin{array}{l}0.2 \\
5 \%\end{array}$ & $0.25 \%$ & $\begin{array}{c}\text { Pengat } \\
\text { ur pH }\end{array}$ \\
\hline $\begin{array}{c}\text { Oleum } \\
\text { rosae }\end{array}$ & $\begin{array}{c}1 \\
\mathrm{~mL}\end{array}$ & $\begin{array}{c}1 \\
\mathrm{~mL}\end{array}$ & $\begin{array}{c}1 \\
\mathrm{~mL}\end{array}$ & $1 \mathrm{~mL}$ & $\begin{array}{c}\text { Pengar } \\
\text { oma }\end{array}$ \\
\hline $\begin{array}{c}\text { Aquades } \\
t\end{array}$ & $\begin{array}{l}\text { Ad } \\
50 \\
\text { mL }\end{array}$ & $\begin{array}{l}\text { Ad } \\
50 \\
\text { mL }\end{array}$ & $\begin{array}{l}\text { Ad } \\
50 \\
\text { mL }\end{array}$ & $\begin{array}{l}\text { Ad } 50 \\
\mathrm{~mL}\end{array}$ & $\begin{array}{c}\text { Pelaru } \\
t\end{array}$ \\
\hline
\end{tabular}

7. Prosedur Kerja Pembuatan Sediaan Sabun Cair Kewanitaan (Feminime Hygiene) Ekstrak Daun Waru

Ditimbang ekstrak daun waru, sodium laurill sulfat, propilen glikol, oleum rosae, setil alkohol, adeps lanae, cera flava, asam sitrat dan aquadest. Dibuat fase minyak dengan melebur setil alkohol, adeps lanae, cera flava pada suhu $70^{\circ} \mathrm{C}$ diatas hot plate, Dibuat fase air dengan melebur sodium laurill sulfat, propilen glikol dan aquadest diatas hot plate pada suhu $70^{\circ} \mathrm{C}$. Dicampurkan fase air kedalam fase minyak dalam lumpang secara bersamaan dan digerus hingga terbentuk emulsi kemudian ditambahkan air sedikit demi sedikit sambil terus digerus, tambahkan ekstrak daun waru, oleum rosae, dan asam sitrat kemudian lalu digerus hingga homogen dan dicukupkan volumenya dengan aquades hingga 50 mL. Dimasukkan ke dalam wadah yang telah disiapkan dan ditutup hingga rapat.

8. Evaluasi Stabilitas Fisik Sediaan Sabun Cair Pembersih Kewanitaan (Feminime Hygiene) Ekstrak Daun Waru

a. Uji Organoleptik

Sediaan dianalisa mengenai bentuk, warna dan bau dari sediaan sabun cair, secara visual.

b. Uji pH

Pengukuran $\mathrm{pH}$ sediaan dilakukan dengan menggunakan kertas pH. Dimasukkan kertas pH kedalam sediaan sabun yang telah dibuat, kemudian ditunggu hingga kertas $\mathrm{pH}$ kering.

c. Uji homogenitas

Sebanyak $1 \mathrm{~mL}$ sediaan sabun ekstrak daun waru dan diletakkan diatas kaca arloji kemudian lalu diraba apakah terdapat butiran kasar pada sediaan tersebut. 
d. Uji Tinggi Busa

Sediaan dipipet sebanyak 1 $\mathrm{mL}$, dimasukkan ke dalam tabung reaksi, kemudian ditambahkan aquades hingga $10 \mathrm{~mL}$, dikocok dengan membolak-balikkan tabung reaksi, lalu segera diukur tinggi busa yang dihasilkan. Lalu, tabung didiamkan selama 5 menit, kemudian diukur lagi tinggi busa yang dihasilkan setelah 5 menit.

e. Uji iritasi

Prinsip Uji iritasi mukosa vagina adalah sediaan uji dipaparkan kedalam lapisan mukosa vagina hewan uji selama tidak kurang dari 5 kali pemaparan dengan selang waktu antar pemaparan 24 jam. Selama pemaparan, jaringan mukosa vagina diamati kemungkinan adanya eritema, eksudat dan udema.

9. Penyiapan Sterilisasi

a. Sterilisasi alat

Adapun prosedur sterilisasi alat dalam penelitian ini yaitu, disiapkan alat yang akan digunakan kemudian dibersihkan alat tersebut dengan sabun dan air dan dikeringkan. Selanjutnya ditutup mulut tabung reaksi dan erlenmeyer dengan menggunakan kapas yang telah dilapisi kain kasa, dibungkus tabung reaksi dan erlenmeyer menggunakan kertas dan dimasukkan alat yang tidak berskala kedalam oven pada suhu $180^{\circ} \mathrm{C}$ selama 2 jam. Sedangkan alat yang berskala dimasukkan kedalam autoklaf dan kunci rapat, kemudian disambungkan pada stok kontak, ditunggu hingga mencapai suhu $121^{\mathrm{O} C}$ selama 15 menit, dibuka tutup/klem autoklaf, dikeluarkan uap dari autoklaf dan dikeluarkan alat-alat yang telah disterilisasi.

b. Sterilisasi media

Adapun prosedur sterilisasi media dalam penelitian ini yaitu terlebih dahulu dibungkus media yang telah dibuat dengan menggunakan kertas kemudian dibuka tutup autoklaf serta aluminiumnya dan dimasukkan media kedalam autoklaf, ditutup rapat autoklaf, lalu di kunci rapat dan disambungkan pada stok kontak, ditunggu hingga mencapai suhu $121^{\circ} \mathrm{C}$ selama 15 menit., dibuka tutup/klem autoklaf dan dikeluarkan uap dari autoklaf, dikeluarkan media yang telah disterilkan, didinginkan kemudian dicairkan hingga larut, media siap digunakan. 
c. Pembuatan Media PDA

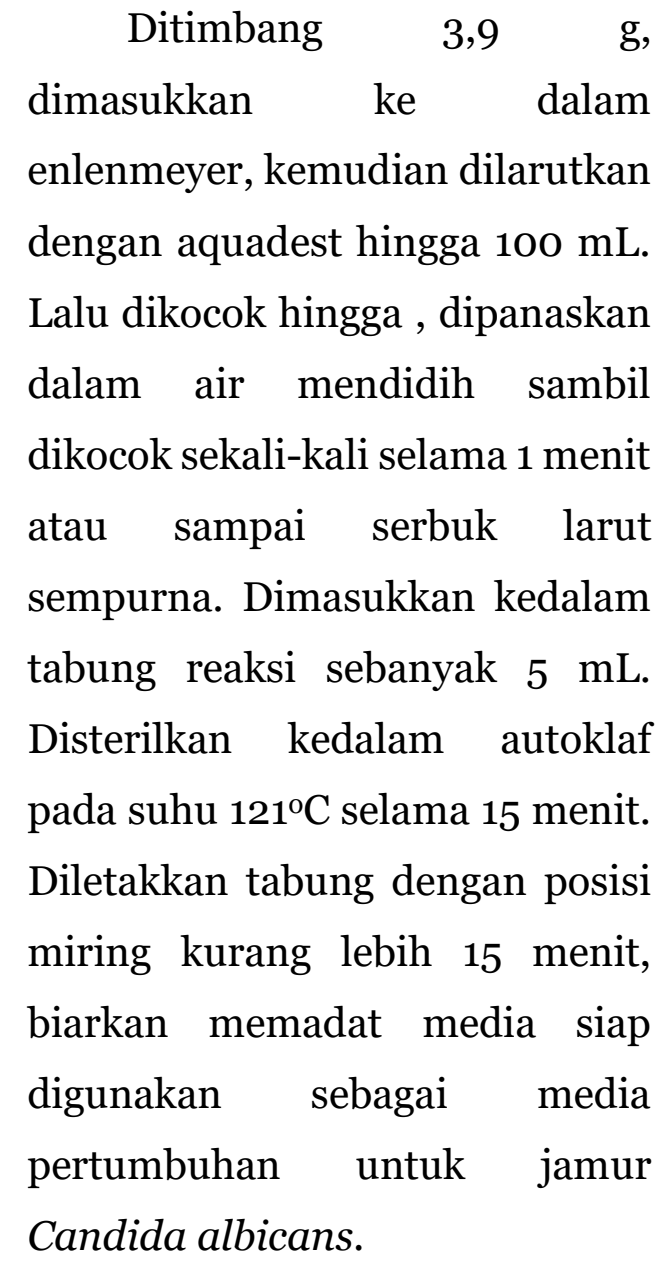

d. Penyiapan Jamur uji

Prosedur penyiapan jamur pada penelitian ini yaitu dilakukan Peremajaan Jamur, diambil satu ose biakan murni jamur Candida albicans dengan menggunakan jarum ose yang telah disterilkan, digoreskan pada media PDA miring, diinkubasi pada suhu $35-37^{\circ} \mathrm{C}$ selama 24 jam. Selanjutnya dilakukan pembuatan suspensi jamur dengan cara sebanyak satu ose biakan jamur Candida albicans yang telah diremajakan dimedia PDA, dimasukkan kedalam tabung reaksi yang telah berisi larutan $\mathrm{NaCl}$ o,9\% sebanyak $9 \mathrm{~mL}$ kemudian dikocok hingga diperoleh suspensi jamur.

10. Pengujian Zona Hambat Sabun Cair Kewanitaan Ekstrak Daun Waru Terhadap Pertumbuhan Jamur Candida albicans dengan metode cakram disk

Sebanyak $1 \mathrm{~mL}$ suspensi mikroba uji dimasukkan ke dalam cawan petri yang masing-masing berisi $15 \mathrm{ml}$ media PDA, Setelah media padat diletakkan kertas cakram steril yang telah dicelupkan sediaan uji. Lalu diinkubasi selama 48 jam pada suhu $30^{\circ} \mathrm{C}$. Diamati adanya pertumbuhan mikroba uji dan diukur daerah hambatan dengan jangka sorong (Anggraini, 2012).

\section{Pengumpulan dan}

\section{Pengelolaan Data}

Pengolahan data pada penelitian ini khusus dilakukan menggunakan Analisis One-Way ANOVA menggunakan perangkat program SPSS versi 20 dengan membandingkan hasil dari pengujian daya hambat sediaan terhadap jamur Candida albicans. 
HASIL DAN PEMBAHASAN

Tabel 1. Hasil Ekstraksi Ekstrak Etanol 96\% Daun Waru Dengan Metode Maserasi

\begin{tabular}{|c|c|c|c|c|}
\hline Pelarut & Berat Serbuk & $\begin{array}{c}\text { Warna Ekstrak } \\
\text { Pekat }\end{array}$ & $\begin{array}{c}\text { Berat Ekstrak } \\
\text { Pekat }\end{array}$ & $\begin{array}{c}\text { Hasil } \\
\text { Rendemen (\%) }\end{array}$ \\
\hline $\begin{array}{c}\text { Etanol } \\
96 \%\end{array}$ & $832,88 \mathrm{gr}$ & $\begin{array}{c}\text { Hijau Pekat } \\
\text { Kehitaman }\end{array}$ & $99,94 \mathrm{gr}$ & $\mathbf{1 1 , 9 9 \%}$ \\
\hline
\end{tabular}

Tabel 2. Hasil dari Uji Fitokimia Ekstrak Daun Waru

\begin{tabular}{|c|l|c|l|}
\hline No & \multicolumn{1}{|c|}{ Senyawa Kimia } & Hasil & \multicolumn{1}{c|}{ Keterangan } \\
\hline 1. & Alkaloid & & \\
\hline & - Dragendrof & $(-)$ & Tidak terbentuk endapan jingga \\
\hline & - Mayer & $(-)$ & $\begin{array}{l}\text { Tidak terbentuk endapan putih hingga } \\
\text { kekuningan }\end{array}$ \\
\hline 2. & Flavanoid & $(+)$ & Terbentuk warna kuning intensif \\
\hline $3 \cdot$ & Saponin & $(+)$ & Terbentuk gelembung dan busa \\
\hline $4 \cdot$ & Sterol & $(+)$ & Terbentuk warna hijau kebiruan \\
\hline $5 \cdot$ & Triterpenoid & $(+)$ & $\begin{array}{l}\text { Terbentuk cincin kecoklatan pada } \\
\text { perbatasan dua pelarut }\end{array}$ \\
\hline 6. & Tannin dan polifenol & $(+)$ & Terbentuk warna biru kehitaman \\
\hline
\end{tabular}

Keterangan:

(+) : Hasil Uji Positif

(-) : : Hasil Uji Negatif

Tabel 3. Hasil dari pemeriksaan organoleptik sediaan sabun cair pembersih kewanitaan ekstrak daun waru

\begin{tabular}{|c|c|c|c|c|c|}
\hline \multirow[t]{2}{*}{ Sediaan } & \multirow[t]{2}{*}{ Pemeriksaan } & \multicolumn{4}{|c|}{ Pengamatan Pada Minggu Ke- } \\
\hline & & I & II & III & IV \\
\hline $\mathrm{A}$ & \multirow[t]{5}{*}{ Warna } & Hijau Pekat & Hijau Pekat & Hijau Pekat & Hijau Pekat \\
\hline $\mathrm{B}$ & & Hijau Pekat & Hijau Pekat & Hijau Pekat & Hijau Pekat \\
\hline $\mathrm{C}$ & & Hijau Pekat & Hijau Pekat & Hijau Pekat & Hijau Pekat \\
\hline $\mathrm{D}$ & & Putih Keruh & Putih Keruh & Putih Keruh & Putih Keruh \\
\hline $\mathrm{E}$ & & Orens Muda & Orens Muda & Orens Muda & Orens Muda \\
\hline $\mathrm{A}$ & \multirow[t]{5}{*}{ Bau/ Aroma } & $\begin{array}{l}\text { Bau khas } \\
\text { mawar }\end{array}$ & $\begin{array}{l}\text { Bau khas } \\
\text { mawar }\end{array}$ & $\begin{array}{l}\text { Bau khas } \\
\text { mawar }\end{array}$ & $\begin{array}{c}\text { Bau khas } \\
\text { mawar }\end{array}$ \\
\hline $\mathrm{B}$ & & $\begin{array}{c}\text { Bau khas } \\
\text { mawar }\end{array}$ & $\begin{array}{c}\text { Bau khas } \\
\text { mawar }\end{array}$ & $\begin{array}{c}\text { Bau khas } \\
\text { mawar }\end{array}$ & $\begin{array}{c}\text { Bau khas } \\
\text { mawar }\end{array}$ \\
\hline $\mathrm{C}$ & & $\begin{array}{c}\text { Bau khas } \\
\text { mawar }\end{array}$ & $\begin{array}{c}\text { Bau khas } \\
\text { mawar }\end{array}$ & $\begin{array}{c}\text { Bau khas } \\
\text { mawar }\end{array}$ & $\begin{array}{l}\text { Bau khas } \\
\text { mawar }\end{array}$ \\
\hline $\mathrm{D}$ & & $\begin{array}{c}\text { Bau khas } \\
\text { mawar }\end{array}$ & $\begin{array}{c}\text { Bau khas } \\
\text { mawar }\end{array}$ & $\begin{array}{c}\text { Bau khas } \\
\text { mawar }\end{array}$ & $\begin{array}{c}\text { Bau khas } \\
\text { mawar }\end{array}$ \\
\hline $\mathrm{E}$ & & $\begin{array}{c}\text { Bau khas } \\
\text { lactacyd } \mathrm{R}\end{array}$ & $\begin{array}{c}\text { Bau khas } \\
\text { lactacyd } \mathbb{R}\end{array}$ & $\begin{array}{c}\text { Bau khas } \\
\text { lactacyd } \mathrm{R}\end{array}$ & $\begin{array}{c}\text { Bau khas } \\
\text { lactacyd } \mathrm{R}\end{array}$ \\
\hline $\mathrm{A}$ & \multirow[t]{5}{*}{ Bentuk } & Cair & Cair & Cair & Cair \\
\hline $\mathrm{B}$ & & Cair & Cair & Cair & Cair \\
\hline $\mathrm{C}$ & & Cair & Cair & Cair & Cair \\
\hline $\mathrm{D}$ & & Cair & Cair & Cair & Cair \\
\hline $\mathrm{E}$ & & Cair & Cair & Cair & Cair \\
\hline
\end{tabular}

Keterangan :

A : Formulasi dengan Konsentrasi Ekstrak 5\%

B : Formulasi dengan Konsentrasi Ekstrak 10\%

C : Formulasi dengan Konsentrasi Ekstrak 15\%

D : Formulasi Sabun Cair Pembersih Kewanitaan Tanpa Ekstrak 
E : Kontrol Positif (Sediaan Sabun Cair Kewanitaan)

Tabel 4. Hasil dari Pemeriksaan pH Sediaan Sabun Cair Pembersih Kewanitaan Ekstrak Daun Waru

\begin{tabular}{|c|c|c|c|c|c|}
\hline \multirow{2}{*}{ Sediaan } & \multicolumn{4}{|c|}{ Pengamatan Minggu Ke- } & \multirow{2}{*}{ Rata-rata } \\
\cline { 2 - 5 } & I & II & III & IV & 3 \\
\hline A & 3 & 3 & 3 & 3 & 4 \\
\hline B & 4 & 4 & 4 & 4 & 4,5 \\
\hline C & 4 & 4 & 5 & 5 & 3 \\
\hline D & 3 & 3 & 3 & 3 & 3 \\
\hline E & 3 & 3 & 3 & 3 & \\
\hline
\end{tabular}

Keterangan :

A : Formulasi dengan Konsentrasi Ekstrak 5\%

B : Formulasi dengan Konsentrasi Ekstrak 10\%

C : Formulasi dengan Konsentrasi Ekstrak 15\%

D : Formulasi Sabun Cair Pembersih Kewanitaan Tanpa Ekstrak

E : Kontrol Positif (Sediaan Sabun Cair Kewanitaan)

Tabel 5. Hasil dari Pemeriksaan Tinggi Busa Sediaan Sabun Cair Pembersih Kewanitaan Ekstrak Daun Waru

\begin{tabular}{|c|c|c|c|c|c|c|c|c|}
\hline \multirow{3}{*}{$\begin{array}{c}\text { Sediaa } \\
\mathbf{n}\end{array}$} & \multicolumn{8}{|c|}{ Pengamatan (Minggu ke) } \\
\hline & \multicolumn{2}{|c|}{ I } & \multicolumn{2}{|c|}{ II } & \multicolumn{2}{|c|}{ III } & \multicolumn{2}{|c|}{ IV } \\
\hline & $\begin{array}{c}\text { Setelah } \\
\text { dikoco } \\
\mathbf{k}\end{array}$ & $\begin{array}{c}\text { Setela } \\
\text { h } 5 \\
\text { menit }\end{array}$ & $\begin{array}{c}\text { Setelah } \\
\text { dikoco } \\
\mathbf{k}\end{array}$ & $\begin{array}{c}\text { Setela } \\
\text { h } 5 \\
\text { menit }\end{array}$ & $\begin{array}{c}\text { Setelah } \\
\text { dikoco } \\
\mathbf{k}\end{array}$ & $\begin{array}{c}\text { Setela } \\
\text { h } 5 \\
\text { menit }\end{array}$ & $\begin{array}{c}\text { Setelah } \\
\text { dikoco } \\
\mathbf{k}\end{array}$ & $\begin{array}{c}\text { Setela } \\
\text { h } 5 \\
\text { menit }\end{array}$ \\
\hline A & $1,5 \mathrm{~cm}$ & $1,5 \mathrm{~cm}$ & $2,5 \mathrm{~cm}$ & $2,5 \mathrm{~cm}$ & $2,5 \mathrm{~cm}$ & $2 \mathrm{~cm}$ & $2 \mathrm{~cm}$ & $2 \mathrm{~cm}$ \\
\hline $\mathrm{B}$ & $1,5 \mathrm{~cm}$ & $1,5 \mathrm{~cm}$ & $2 \mathrm{~cm}$ & $2 \mathrm{~cm}$ & $2 \mathrm{~cm}$ & $2 \mathrm{~cm}$ & $2 \mathrm{~cm}$ & $2 \mathrm{~cm}$ \\
\hline $\mathrm{C}$ & $1 \mathrm{~cm}$ & $1 \mathrm{~cm}$ & $2 \mathrm{~cm}$ & $1,5 \mathrm{~cm}$ & $2 \mathrm{~cm}$ & $2 \mathrm{~cm}$ & $2 \mathrm{~cm}$ & $2 \mathrm{~cm}$ \\
\hline $\mathrm{D}$ & $1 \mathrm{~cm}$ & $1 \mathrm{~cm}$ & $2,5 \mathrm{~cm}$ & $2,5 \mathrm{~cm}$ & $2 \mathrm{~cm}$ & $2 \mathrm{~cm}$ & $2 \mathrm{~cm}$ & $2 \mathrm{~cm}$ \\
\hline $\mathrm{E}$ & $2 \mathrm{~cm}$ & $2 \mathrm{~cm}$ & $2 \mathrm{~cm}$ & $2 \mathrm{~cm}$ & $2 \mathrm{~cm}$ & $2 \mathrm{~cm}$ & $2 \mathrm{~cm}$ & $2 \mathrm{~cm}$ \\
\hline
\end{tabular}

Keterangan :

A : Formulasi dengan Konsentrasi Ekstrak 5\%

B : Formulasi dengan Konsentrasi Ekstrak 10\%

C : Formulasi dengan Konsentrasi Ekstrak 15\%

D : Formulasi Sabun Cair Pembersih Kewanitaan Tanpa Ekstrak

E : Kontrol Positif (Sediaan Sabun Cair Kewanitaan)

Tabel 6. Hasil dari Pemeriksaan homogenitas Sediaan Sabun Cair Pembersih Kewanitaan Ekstrak Daun Waru

\begin{tabular}{|c|c|c|c|c|}
\hline \multirow{2}{*}{ Sediaan } & \multicolumn{4}{|c|}{ Pengamatan Minggu Ke- } \\
\cline { 2 - 5 } & I & II & III & IV \\
\hline A & Homogen & Homogen & Homogen & Tidak Homogen \\
\hline B & Homogen & Homogen & Homogen & Homogen \\
\hline C & Homogen & Homogen & Homogen & Homogen \\
\hline D & Homogen & Homogen & Tidak Homogen & Tidak Homogen \\
\hline E & Tidak Homogen & Tidak Homogen & Tidak Homogen & Tidak Homogen \\
\hline
\end{tabular}

Keterangan :

A : Formulasi dengan Konsentrasi Ekstrak 5\%

B : Formulasi dengan Konsentrasi Ekstrak 10\%

C : Formulasi dengan Konsentrasi Ekstrak 15\%

D : Formulasi Sabun Cair Pembersih Kewanitaan Tanpa Ekstrak

E : Kontrol Positif (Sediaan Sabun Cair Kewanitaan) 
Tabel 7. Hasil Uji Iritasi Sabun Cair Pembersih Kewanitaan Ekstrak Daun Waru

\begin{tabular}{|c|c|c|c|c|c|}
\hline \multirow{2}{*}{ Sediaan } & \multicolumn{5}{|c|}{ Pengamatan hari ke- } \\
\cline { 2 - 6 } & I & II & III & IV & V \\
\hline A & $\begin{array}{c}\text { Tidak } \\
\text { mengiritasi }\end{array}$ & $\begin{array}{c}\text { Tidak } \\
\text { mengiritasi }\end{array}$ & $\begin{array}{c}\text { Tidak } \\
\text { mengiritasi }\end{array}$ & $\begin{array}{c}\text { Tidak } \\
\text { mengiritasi }\end{array}$ & $\begin{array}{c}\text { Tidak } \\
\text { mengiritasi }\end{array}$ \\
\hline $\mathrm{B}$ & $\begin{array}{c}\text { Tidak } \\
\text { mengiritasi }\end{array}$ & $\begin{array}{c}\text { Tidak } \\
\text { mengiritasi }\end{array}$ & $\begin{array}{c}\text { Tidak } \\
\text { mengiritasi }\end{array}$ & $\begin{array}{c}\text { Tidak } \\
\text { mengiritasi }\end{array}$ & $\begin{array}{c}\text { Tidak } \\
\text { mengiritasi }\end{array}$ \\
\hline $\mathrm{C}$ & $\begin{array}{c}\text { Tidak } \\
\text { mengiritasi }\end{array}$ & $\begin{array}{c}\text { Tidak } \\
\text { mengiritasi }\end{array}$ & $\begin{array}{c}\text { Tidak } \\
\text { mengiritasi }\end{array}$ & $\begin{array}{c}\text { Tidak } \\
\text { mengiritasi }\end{array}$ & $\begin{array}{c}\text { Tidak } \\
\text { mengiritasi }\end{array}$ \\
& Tidak & $\begin{array}{c}\text { Tidak } \\
\text { mengiritasi }\end{array}$ & $\begin{array}{c}\text { Tidak } \\
\text { mengiritasi }\end{array}$ & $\begin{array}{c}\text { Tidak } \\
\text { mengiritasi }\end{array}$ & $\begin{array}{c}\text { Tidak } \\
\text { mengiritasi }\end{array}$ \\
\hline $\mathrm{D}$ & $\begin{array}{c}\text { Tidak } \\
\text { mengiritasi }\end{array}$ & $\begin{array}{c}\text { Tidak } \\
\text { mengiritasi }\end{array}$ & $\begin{array}{c}\text { Tidak } \\
\text { mengiritasi }\end{array}$ & $\begin{array}{c}\text { Tidak } \\
\text { mengiritasi }\end{array}$ \\
\hline
\end{tabular}

\section{Keterangan :}

A : Formulasi dengan Konsentrasi Ekstrak 5\%

B : Formulasi dengan Konsentrasi Ekstrak 10\%

C : Formulasi dengan Konsentrasi Ekstrak 15\%

D : Formulasi Sabun Cair Pembersih Kewanitaan Tanpa Ekstrak

E : Kontrol Positif (Sediaan Sabun Cair Kewanitaan)

Tabel 8. Hasil diameter zona hambat ekstrak daun waru dengan metode cakram disk

\begin{tabular}{|c|c|c|c|c|c|}
\hline \multirow{2}{*}{ No } & \multirow{2}{*}{ Konsentrasi } & \multicolumn{3}{|c|}{ Reflikasi } & \multirow[b]{2}{*}{ Rata-rata (mm) } \\
\hline & & I & II & III & \\
\hline 1. & $5 \%$ & 11 & 10 & 10 & $10.33 \mathrm{~mm}$ \\
\hline 2. & $10 \%$ & 12 & 12 & 12 & $12 \mathrm{~mm}$ \\
\hline 3. & $15 \%$ & 11 & 11 & 11 & $11 \mathrm{~mm}$ \\
\hline
\end{tabular}

Tabel 9. Rata-rata hasil diameter zona hambat sediaan Sabun Cair Pembersih Kewanitaan daun Waru dengan metode Cakram disk

\begin{tabular}{|c|c|c|c|c|c|}
\hline \multirow{2}{*}{ Sediaan } & \multirow{2}{*}{$\begin{array}{c}\text { Pemeriksaa } \\
\text { n }\end{array}$} & \multicolumn{4}{|c|}{ Hasil Pengamatan } \\
\hline & & $\begin{array}{c}\text { Perlakuan } \\
\text { I }\end{array}$ & $\begin{array}{c}\text { Perlakuan } \\
\text { II }\end{array}$ & $\begin{array}{c}\text { Perlakuan } \\
\text { III }\end{array}$ & $\begin{array}{c}\text { Rata-rata } \\
(\mathbf{m m})\end{array}$ \\
\hline A (5\%) & \multirow{5}{*}{$\begin{array}{l}\text { Jamur } \\
\text { Candida } \\
\text { albicans }\end{array}$} & $21,66 \mathrm{~mm}$ & $20.33 \mathrm{~mm}$ & $21,33 \mathrm{~mm}$ & $21,10 \mathrm{~mm}$ \\
\hline $\mathrm{B}(10 \%)$ & & $22,66 \mathrm{~mm}$ & $21,33 \mathrm{~mm}$ & $21,33 \mathrm{~mm}$ & $21,77 \mathrm{~mm}$ \\
\hline $\mathrm{C}(15 \%)$ & & $20 \mathrm{~mm}$ & $20 \mathrm{~mm}$ & $21,66 \mathrm{~mm}$ & $20.55 \mathrm{~mm}$ \\
\hline $\begin{array}{c}\mathrm{D} \\
(\text { Lactacyd } \Omega)\end{array}$ & & $15,66 \mathrm{~mm}$ & $13,66 \mathrm{~mm}$ & $16,66 \mathrm{~mm}$ & $15,32 \mathrm{~mm}$ \\
\hline $\begin{array}{c}\mathrm{E} \\
\text { (Blanko) }\end{array}$ & & $16 \mathrm{~mm}$ & $20 \mathrm{~mm}$ & $20 \mathrm{~mm}$ & $18,66 \mathrm{~mm}$ \\
\hline
\end{tabular}

Keterangan :

Perlakuan I : Hasil Rata-rata dari $\mathrm{A}_{1} \mathrm{~B}_{1} \mathrm{C}_{1} \mathrm{D}_{1} \mathrm{E}_{1}$

Perlakuan II : Hasil Rata-rata dari $\mathrm{A}_{2} \mathrm{~B}_{2} \mathrm{C}_{2} \mathrm{D}_{2} \mathrm{E}_{2}$

Perlakuan III : Hasil Rata-rata dari $\mathrm{A}_{3} \mathrm{~B}_{3} \mathrm{C}_{3} \mathrm{D}_{3} \mathrm{E}_{3}$ 


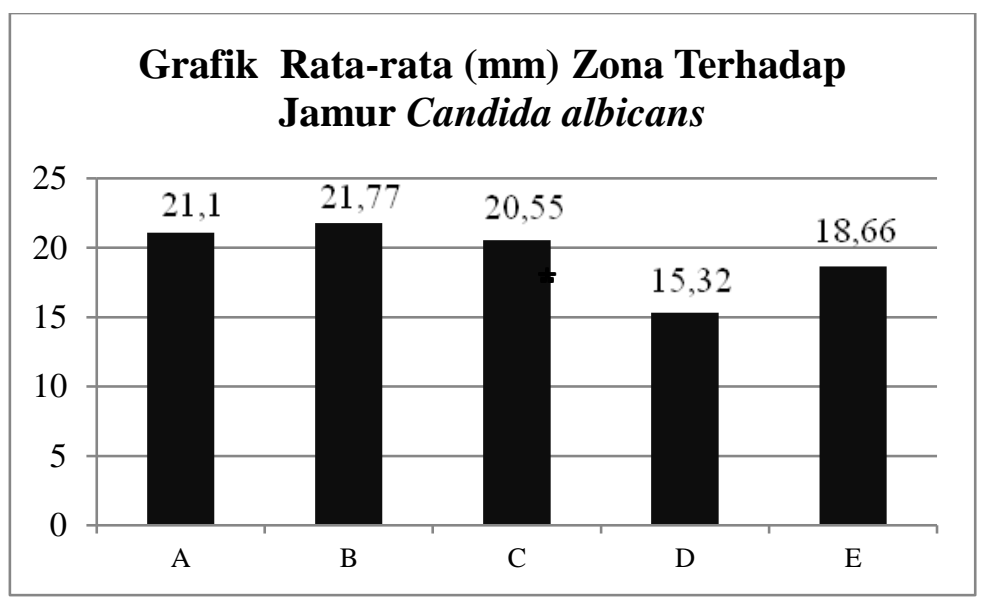

Gambar 1. Grafik Deviasi Zona Hambat Sediaan Sabun Cair Pembersih Kewanitaan Ekstrak Daun Keterangan:

Waru

A : Daya hambat sediaan dengan konsenstrasi ekstrak $5 \%$

B : Daya hambat sediaan dengan konsenstrasi ekstrak 10\%

C : Daya hambat sediaan dengan konsenstrasi ekstrak $15 \%$

D : Daya hambat sediaan Lactacyd ${ }^{\circledR}$

E : Daya hambat blanko (sediaan tanpa ekstrak)

Sampel yang digunakan pada penelitian ini ialah tumbuhan daun waru (Hibiscus tiliaceus). Daun waru yang digunakan pada penelitian ini diperoleh di desa Lalongngowuna Kecamatan Tongauna Kabupaten Konawe karena didaerah tersebut banyak tumbuh ditepi sungai. Pengambilan sampel dilakukan pada pagi hari karena saat pagi hari intensitas cahaya matahari masih rendah, suhu lingkungan rendah, kelembaban udara tinggi, sehingga tingkat evaporasi rendah, transpirasi tanaman rendah, dan tekanan turgor tanaman menjadi tinggi yang ditandai dengan kondisi fisik daun yang segar dan hijau (Dwinatari, 2015). Setelah proses pengambilan sampel, dilakukan pengeringan dan penyerbukan.
Metode maserasi dipilih karena dapat mengekstraksi senyawa aktif dengan baik melalui perendaman tanpa pemanasan sehingga dapat menghindari kerusakan komponen senyawa yang labil dan tidak tahan panas (Dean.2009). Pelarut yang digunakan yaitu etanol $96 \%$, pemilihan pelarut tersebut karena lebih mudah melarutkan senyawa-senyawa metabolit aktif yang berefek sebagai antijamur seperti fenol, tanin, dan flavanoid. Metode tersebut dilakukan selama 3 hari dengan sesekali pengadukan yang bertujuan agar semua bagian simplisia dapat bercampur dengan etanol kemudian dilanjutkan dengan penyaringan, Filtrat kemudian dipekatkan dengan 
rotary evaporator (Dwicahyani, dkk.,2019)

Hasil Ekstrak daun waru ditunjukkan pada tabel 1 dengan perhitungan rendemen yang diperoleh sebesar 11,99\%. Perhitungan rendemen ini dapat berfungsi untuk mengetahui berapa persentase jumlah ekstrak daun waru dengan simplisia daun waru yang digunakan. Ekstrak kental yang diperoleh akan dilakukan skrining fitokimia serta dilanjutkan ke tahap formulasi.

Skrining fitokimia dilakukan untuk mengetahui kandungan ekstrak daun waru. Skrining fitokimia dilakukan meliputi uji alkaloid, tanin dan polifenol, sterol dan triterpenoid, saponin dan flavanoid. Berdasarkan Tabel 2 diketahui bahwa ekstrak daun waru mengandung senyawa flavonoid, tanin, saponin, polifenol, triterpenoid dan sterol. Sedangkan kandungan senyawa alkaloid tidak terkandung dalam ekstrak daun waru. Dimana pada uji flavanoid menunjukkan hasil positif dengan terbentuknya warna kuning intensif, pada uji tanin dan polifenol menunjukan hasil positif yang ditunjukkan dengan terbentuknya warna hitam kehijauan, pada uji saponin menunjukkan hasil positif karena setelah proses pengocokan timbul busa, pada uji triterpenoid menunjukkan hasil dengan terbentuknya cincin kecoklatan, uji sterol menunjukkan warna hijau kebiruan, dan pada uji alkaloid menunjukkan hasil negatif karena tidak terbentuk endapan putih hingga kukuningan. Hasil yang diperoleh tersebut tidak sesuai dengan hasil skrining fitokimia yang dilakukan oleh Supartono (2016) yang meliputi uji alkaloid, saponin, flavanoid dan tanin dimana pada uji yang dilakukannya ekstrak daun waru positif mengandung senyawa alkaloid, saponin, dan tanin sedangkan untuk flavanoid tidak terkandung dalam ekstrak daun waru dan pada uji skrining fitokimia yang dilakukan oleh Lusiana (2013) yang meliputi uji saponin, tanin, polifenol, flavanoid, sterol dan triterpenoid, ekstrak daun waru mengandung senyawa saponin, steroid, tanin, polifenol, dan flavanoid sedangan triterpenoid tidak terkandung dalam ekstrak daun waru. Adanya perbedaan hasil yang diperoleh dikarenakan perbedaan kondisi lingkungan tiap suatu daerah itu berbeda-beda mulai dari suhu hingga tanahnya hal ini sejalan dengan Marini (2016) mengatakan bahwa adanya perbedaan hasil dikarenakan dari kandungan hara tanah dan menurut Meisarani (2016) 
perbedaan hasil yang diperoleh karena pengaruh kondisi lingkungan.

Evaluasi stabilitas fisik sediaan sabun cair pembersih kewanitaan meliputi pengamatan organoleptik, pengukuran $\mathrm{pH}, \quad$ pengujian homogenitas, tinggi busa. Evaluasi aktivitasnya diamati menggunakan metode pengujian iritasi serta uji aktivitas sediaan sabun cair pembersih kewanitaan terhadap jamur Candida albicans.

Uji organoleptik dilakukan untuk mengetahui karakteristik fisik sabun cair pembersih kewanitaan ekstrak daun waru apakah telah memenuhi kriteria yang diinginkan atau tidak. Pengujian ini dilakukan secara visual berdasarkan karakteristik bentuk, warna dan bau sediaan sabun cair pembersih kewanitaan, pemeriksaan organoleptik dilakukan selama 4 minggu. Berdasarkan hasil pengamatan organoleptik menunjukkan bahwa sediaan sabun cair pembersih kewanitaan ekstrak daun waru dengan berbagai konsentrasi seperti $5 \%, 10 \%$ dan $15 \%$ dari minggu pertama hingga keempat tetap berwarna hijau pekat, bau khas mawar, cair dan tidak ada pertumbuhan bakteri maupun jamur, hal tersebut menunjukkan bahwa sediaan sabun cair pembersih kewanitaan stabil selama penyimpanan pada suhu kamar $\left(25^{\circ} \mathrm{C}\right)$, dimana hal tersebut dapat dilihat pada tabel 3 .

Uji pH merupakan salah satu syarat mutu sabun cair kewanitaan. Hal tersebut bertujuan untuk mengetahui keamanan sediaan saat digunakan agar tidak mengiritasi kulit bagian kewanitaan dan dapat menimbulkan masalah dan merusak flora normal dalam vagina jika $\mathrm{pH}$-nya tidak sesuai dengan $\mathrm{pH}$ pada daerah kewanitaan. Berdasarkan uji pH yang dilakukan dari minggu pertama hingga keempat sediaan sabun cair pembersih kewanitaan ekstrak daun waru dengan konsentrasi ekstrak 5\% memiliki pH 3, konsentrasi $10 \%$ memiliki $\mathrm{pH} 4$ dan konsentrasi $15 \%$ pada minggu pertama hingga kedua memiliki pH 4 dan pada minggu ketiga dan keempat memiliki $\mathrm{pH} 5$ walaupun terjadi perubahan $\mathrm{pH}$ pada konsentrasi $15 \%$ pada minggu ketiga dan keempat namun $\mathrm{pH}$ tersebut masih masuk dalam range $\mathrm{pH}$ sediaan sabun cair kewanitaan, dimana menurut Chusniasih (2018) persyaratan $\mathrm{pH}$ sabun cair pembersih kewanitaan yang sesuai dengan $\mathrm{pH}$ normal daerah kewanitaan yaitu $\mathrm{pH}$ 3,5-4,5 dan persyaratan $\mathrm{pH}$ sediaan sabun cair pembersih kewanitaan menurut mutmainah (2016) berkisar antara pH $5.5-8,5$ nilai tersebut tidak 
akan mengganggu flora normal bakteri dalam vagina.

Berdasarkan hasil pengukuran uji tinggi busa pada sediaan sabun cair pembersih kewanitaan menunjukkan bahwa tidak adanya perbedaan yang secara signifikan pada minggu pertama hingga minggu keempat, hasil tinggi busa diperoleh sediaan dengan konsentrasi ekstrak 5\% memiliki tinggi busa $1,5 \mathrm{~cm}$ hingga $2,5 \mathrm{~cm}$, konsentrasi 10\% memiliki tinggi busa $1,5 \mathrm{~cm}$ hingga $2 \mathrm{~cm}$ dan konsentrasi 15\% memiliki tinggi busa antara $1 \mathrm{~cm}$ hingga $2 \mathrm{~cm}$ hal tersebut dapat dilihat pada tabel 5 . Adanya perbedaan tinggi busa yang diperoleh dari ketiga sediaan selama pengujian dikarenakan timbulnya busa diakibatkan oleh adanya pengocokan sementara pengocokkan ini dilakukan oleh manusia sehingga kekuatan pengocokkan itu tidak bisa distabilkan sehingga hasil tinggi busa tidak sama tiap waktu hal ini sejalan dengan pernyataan Jusnita (2017) adanya perbedaan tinggi busa dari sediaan dikarenakan dari kuatnya pengojokkan pada saat pengujian. Uji tinggi busa dilakukan untuk melihat seberapa banyak busa dihasilkan. Tidak ada syarat tinggi busa minimum atau maksimum untuk suatu produk karena tinggi busa tidak menunjukkan kemampuan dalam membersihkan. Hal ini sejalan dengan pernyataan anggraini (2012) dimana hal tersebut dikaitkan pada nilai estetika yang disukai konsumen, namun untuk sabun pembersih kewanitaan (feminine hygiene) tidak boleh tinggi atau busa harus rendah.

Pemeriksaan homogenitas sediaan sabun cair pembersih kewanitaan ekstrak daun waru yang dilakukan dari minggu pertama hingga keempat menunjukkan bahwa pada minggu pertama hingga minggu kedua sediaan dengan konsentrasi ekstrak 5\%, 10\% 15\% dan blanko homogen dan sediaan E tidak homogen. Pada minggu ketiga sediaan yang homogen ialah sediaan dengan konsentrasi ekstrak 5\%, 10\% dan 15\% sedangkan sediaan blanko serta lactacyd $\AA$ tidak homogen dan pada minggu keempat sediaan yang homogen ialah sediaan dengan konsentrasi ekstrak 10\% dan 15\% sedangkan sediaan dengan konsentrasi 5\%, blanko dan lactacyd® tidak homogen, hal tersebut dapat dilihat pada tabel 6. Penyebab ketidak homogenan yang terjadi pada mingga keempat terhadap sediaan dengan konsentrasi ekstrak 5\% dikarenakan konsentrasi ekstraknya masih sedikit sehingga intensitas warnanya itu tidak sepekat dengan konsentrasi ekstrak 10\% dan $15 \%$ jadi homogenitasnya 
masih dapat terlihat, dan didukung juga dengan sediaan blanko dimana pada minggu ketiga sediaan blanko tersebut tidak homogen, karena sediaan blanko tersebut tidak stabil dan berhubung sediaan dengan konsentrasi $5 \%$ intensitas warnanya masih dapat terlihat homogen atau tidaknya sehingga pada minggu keempat sediaan dengan konsentrasi $5 \%$ jadi tidak homogen jadi ketidak homogenannya sesuai dengan sediaan blanko sedangkan untuk konsentrasi 10\% dan 15\% tetap homogen terlihat karena intensitas warnanya terlalu gelap jadi tidak ada perbedaan antara homogenitas dengan warna ekstraknya dimana sudah menyatu dengan sediaan serta didukung juga oleh kontrol positif (lactacyd $囚$ ) yang digunakan dimana dari awal semenjak dibeli sudah tidak homogen sehingga untuk homogenitas pada sediaan sabun cair kewanitaan tidak terlalu dipermasalahkan.

Uji iritasi dilakukan untuk mengetahui apakah sediaan aman untuk digunakan atau tidak. Berdasarkan tabel 7 menunjukkan bahwa sediaan sabun pembersih kewanitaan (feminine hygiene) dengan konsentrasi ekstrak 5\%, 10\% dan 15\% tidak mengiritasi hal tersebut ditandai dengan tidak adanya edema atau pembengkakan dan eritema atau kemerahan yang timbul pada vagina kelinci dimana pengamatan edema dan eritema dilakukan secara visual dan diraba sehingga dapat dinyatakan bahwa sabun pembersih kewanitaan (feminine hygiene) tidak dapat mengiritasi kulit, hal ini sejalan dengan penelitian yang dilakukan oleh Rahmi (2017) dimana ia mengatakan bahwa sediaan sabun cair pembersih kewanitaan yang tidak dapat mengiritasi dapat ditandai dengan tidak adanya edema atau eritema pada kulit.

Pengujian aktivitas antijamur bertujuan untuk menentukan kemampuan ekstrak daun waru (Hibiscus tiliaceus) dalam menghambat pertumbuhan jamur. Dilakukan dengan menggunakan metode cakram disk, penggunaan metode ini karena teknik yang sederhana dan mudah. Jamur yang digunakan dalam pengujian ini ialah Candida albicans karena jamur tersebut merupakan penyebab keputihan yang paling utama pada wanita. Media PDA (Potato Dekstrosa Agar) digunakan pada pengujian ini karena media tersebut biasa digunakan untuk media pertumbuhan jamur.

Diameter zona hambat terhadap jamur Candida albicans dipengaruhi oleh konsentrasi ekstrak daun waru, 
serta dalam pengukuran zona hambat dapat diketahui terbentuknya zona bening yang terdapat disekitar cakram disk. Pada penelitian ini menggunakan tiga perlakuan dan disetiap perlakuan terdiri dari tiga ulangan.

Pengujian zona hambat pada media cakram disk dengan mengisi kontrol positif, kontrol negatif dan sediaan sabun cair pembersih kewanitaan ekstrak daun waru dengan masing-masing konsentrasi yaitu $5 \%$, $10 \%$ dan $15 \%$ pada media yang telah diinokulasi jamur Candida albicans didalam cawan petri.

Pengujian daya hambat digunakan lactacyd $®$ sebagai kontrol positif dan blanko (sediaan tanpa ekstrak) sebagai kontrol negatif. Kontrol positif berfungsi untuk membandingkan daya hambat dari kelompok perlakuan (sampel) dengan obat kimia yang sering digunakan sebagai anti jamur, sedangkan kontrol negatif digunakan untuk mengetahui apakah pelarut dan bahan tambahan yang digunakan dapat mempengaruhi hasil uji anti jamur atau tidak. Hasil pengamatan zona hambat ekstrak daun waru dan sediaan sabun cair pembersih kewanitaan dalam berbagai konsentrasi diketahui bahwa ekstrak daun waru mampu menghambat pertumbuhan jamur Candida albicans.
Berdasarkan tabel 8 sediaan sabun pembersih kewanitaan ekstrak daun waru yang memiliki aktivitas tertinggi dalam menghambat pertumbuhan jamur Candida albicans ialah pada konsentrasi $10 \%$ dengan zona hambat 21,77 mm. Jika dibandingkan dengan kontrol negatif (blanko tanpa ekstrak) dan kontrol positif (lactacyd $囚$ ) daya hambat sediaan sabun pembersih kewanitaan dengan konsentrasi 5\%, $10 \%$ dan $15 \%$ masih memiliki daya hambat yang lebih tinggi, dimana zona hambat sediaan dengan konsentrasi $5 \%$ ialah 21,10 $\mathrm{mm}$, sediaan dengan konsentrasi $10 \%$ ialah $21.77 \mathrm{~mm}$ dan untuk sediaan konsentrasi $15 \%$ ialah 20,55 mm sedangkan untuk kontrol negatif zona hambatnya ialah 18,66 mm dan untuk kontrol positif zona hambatnya ialah $15,32 \mathrm{~mm}$ dan untuk daya hambat ekstrak daun waru berdasarkan tabel 9 hasil pengujian diperoleh bahwa konsentrasi ekstrak daun waru yang memiliki aktivitas tertinggi dalam menghambat pertumbuhan Candida albicans ialah pada konsentrasi 10\% dengan zona hambat $12 \mathrm{~mm}$.

Adanya perbedaan daya hambat yang diperoleh dimana konsentrasi 10\% lebih memiliki daya hambat yang lebih tinggi dibandingkan dengan sediaan yang konsentrasi $15 \%$ 
dikarenakan kemampuan hambat maksimum dari ekstrak tersebut berada pada konsentrasi 10\% dan menurut Ardelia (2010) perbedaan konsentrasi diameter zona hambat pada berbagai konsentrasi menunjukkan bahwa perbedaan konsentrasi mempengaruhi efektivitas suatu obat. Dalam hal ini, sediaan sabun pembersih kewanitaan ekstrak daun waru $10 \%$ memberikan zona hambat yang paling luas terhadap pertumbuhan jamur Candida albicans dibandingkan dengan konsentrasi lainnya. Dimana sediaan dengan konsentrasi $15 \%$ justru memberikan efek yang lebih kecil dibanding dengan sediaan yang konsentrasi $10 \%$ dan $5 \%$. Dengan demikian, konsentrasi paling besar belum tentu memberikan daerah hambat yang paling luas. Hal ini dapat terjadi karena bioaktivitas suatu fitofarmaka sangat dipengaruhi oleh interaksi senyawa yang ada didalamnya.

Terbentuknya zona hambat pada masing-masing sediaan dengan konsentrasi ekstrak 5\%, 10\% dan 15\% dikarenakan adanya zat-zat aktif atau senyawa metabolit sekunder yang dapat menghambat pertumbuhan jamur Candida albicans. Dimana ekstrak daun waru mengandung senyawa yang dapat berkhasiat sebagai antijamur diantaranya flavanoid, saponin, sterol dan triterpenoid serta tanin dan polifenol.

Senyawa antijamur mempunyai berbagai mekanisme penghambatan terhadap sel jamur. Djunaedy (2008) menyatakan bahwa senyawa antijamur memiliki mekanisme kerja dengan cara menetralisasi enzim yang terkait dalam invasi dan kolonisasi jamur, merusak membran sel jamur, menghambat sistem enzim jamur sehingga mengganggu terbentuknya ujung hifa dan mempengaruhi sintesis asam nukleat dan protein.

Flavonoid merupakan golongan terbesar dari senyawa polifenol. Flavonoid bekerja dengan cara denaturasi protein sehingga meningkatkan permeabilitas membran sel. Denaturasi protein menyebabkan gangguan dalam pembentukan sel sehingga merubah komposisi komponen protein (Wahyuningtyas, 2008). Cowan (1999) dalam Firdaus (2015), menambahkan bahwa senyawa fenol yang terdapat pada flavonoid dapat mendenaturasi protein sel dan mengerutkan dinding sel sehingga menyebaban lisisnya dinding sel jamur. Selain itu, senyawa fenol melalui gugus hidroksi yang akan berikatan dengan gugus sulfihidril dari protein jamur sehingga mampu 
mengubah konformasi protein membran sel target yang mengakibatkan pertumbuhan sel jamur terganggu bahkan dapat mengalami kematian.

Saponin merupakan golongan metabolit yang dapat menghambat atau membunuh Candida albicans dengan cara menurunkan tegangan permukaan membran sterol dari dinding sel Candida albicans, sehingga permeabilitasnya meningkat. Permeabilitas yang meningkat mengakibatkan cairan intraseluler yang lebih pekat tertarik keluar sel sehingga nutrisi, zat-zat metabolisme, enzim, protein dalam sel keluar dan jamur mengalami kematian (Hardiningtyas, 2009). Ismaini (2011) menambahkan, triterpenoid bersifat toksik yang dapat menimbulkan kerusakan pada organel-organel sel sehingga menghambat terjadinya pertumbuhan jamur patogen.

Hasil dari pengujian aktivitas antijamur terhadap jamur Candida albicans dilakukan uji statistik dengan One-Way ANNOVA dan dilanjutkan dengan analisis LSD untuk mengetahui ada tidaknya pengaruh konsentrasi terhadap zona hambat yang dihasilkan.

Berdasarkan hasil uji statistik One-Way ANNOVA diperoleh hasil yang signifikan dengan nilai o,01 yang berarti lebih kecil dari $0,05(\mathrm{p}<0,05)$ maka $\mathrm{H}_{\mathrm{o}}$ ditolak sehingga bisa disimpulkan bahwa sediaan sabun cair pembersih kewanitaan ekstrak daun waru memiliki aktivitas antijamur. Analisis lanjutan LSD dilakukan untuk mengetahui perbedaan setiap konsentrasi sediaan sabun cair pembersih kewanitaan, hasil uji analisis LSD menunjukkan tidak adanya perbedaan efek daya hambat yang signifikan dari ketiga sediaan dengan konsentrasi $5 \%, 10 \%$ dan $15 \%$.

\section{KESIMPULAN}

Berdasarkan uraian hasil penelitian diatas maka dapat disimpulkan bahwa sediaan sabun cair pembersih kewanitaan Ekstrak Daun Waru memenuhi syarat stabilitas fisik sediaan yang meliputi uji Organoleptik, $\mathrm{pH}$, Homogenitas, dan Tinggi Busa, pada formula dengan konsentrasi $5 \%$, 10\% dan 15\% dan juga Sabun cair pembersih kewanitaan ekstrak daun waru dengan konsentrasi $5 \%$ memiliki aktivitas antijamur Candida albicans dengan hasil zona hambat 21,10 $\mathrm{mm}$ dengan kategori kuat, konsentrasi 10\% memiliki zona hambat $21,77 \mathrm{~mm}$ dengan katergori kuat dan konsentrasi $15 \%$ memiliki zona hambat 20,55 mm dengan katergori kuat dimana $(\mathrm{p}<0,05)$ yaitu o,01 dengan pengujian One Way ANNOVA. 
UCAPAN TERIMA KASIH

Dengan selesainya penelitian

ini, penulis mengucapkan terima kasih kepada semua pihak yang telah berkontribusi yaitu Dr. PH. Hj. Tasnim, S.KM., M.PH, selaku ketua STIKES Mandala Waluya Kendari, Apt. Waode Yuliastri, S.Farm.,M.Si selaku selaku Ketua Program Studi Farmasi STIKES Mandala Waluya Kendari, Staf Administrasi STIKES Mandala Waluya Kendari, Laboratorium FarmakognosiFitokimia dan Biofarmasi STIKES Mandala Waluya Kendari, mahasiswa(i) Program Studi Farmasi STIKES Mandala Waluya Kendari, serta seluruh pihak yang telah membantu selama penulis melakukan penelitian.

\section{DAFTAR PUSTAKA}

Anggraini. 2012. Formulasi Sabun Cair dari Ekstrak Batang Nanas (Ananas comosus L) Untuk Mengatasi Jamur Candida Albicans. Padang : STIFA Riau

Ardelia, Patra Inova., Andrizi Fauziah., dan Hamidy Yulis M. 2010. Aktivitas Antijamur Air Perasan Daun Seledri (Apium graveolens L.) Terhadap Candida albicans Secara In Vitro. Fakultas Kedokteran Riau: Riau

Dwicahyani, U., Isrul, M., \& Noviyanti, W. O. N. 2019. Formulasi Sediaan Lipstik Ekstrak Kulit Buah Ruruhi (Syzygium policephalum Merr) Sebagai Pewarna. Jurnal Mandala Pharmacon Indonesia, 5(02), 91-103.

Chusniasih, Dewi., Elsyana Vida, dan Susanti Fauziah Arini. 2018. Uji Efektivitas Antijamur Sabun Cair Pembersih Kewanitaan Ekstrak Aseton Daun Jambu Bïi Terhadap
Candida albicans. Program Studi Sarjana Farmasi Universitas Malahayati

Djunaedy, A. 2008. Aplikasi Fungisida Sistemik dan Pemanfaatan Mikoriza dalam Rangka

Pengendalian Patogen Tular Tanah pada Tanaman Kedelai (Glycine max L.). Embryo, 5 (2):149-157.

Dwinatari, Kurnia Indrawan., dan Murti Bayu Yosi, 2015. The Effect Of Harvesting Time And Degree of Leaves Maturation On Vitexecarpin Level In Legundi Leaves (Vitex trifolia L.). Universitas Gadjah Mada: Yogyakarta

Darma, muhammad, dkk. 2017. Hubungan pengetahuan,vulva

hygiene,stres,danpola

makandengan kejadian infeksi flour albus(keputihan) pada remaja siswi sma negeri 6 kendari 2017. Fakultas Kesehatan Masyarakat Universitas Halu Oleo: Kendari

Direktorat Jendral Pengawas Obat dan Makanan. 2001. Inventaris Tanaman Obat Indonesia. Departemen Kesehatan Republik Indonesia Badan Penelitian dan Pengembangan Kesehatan: Jakarta

Elin, Yulinah, S., Retnosari, Andjarwati., I Sigit., Ketut, I Adnyana., Prayitno, A. S., dan Kusnandar. 2008. Iso Farmakoterapi. Jakarta: ISFI

Handayani, A.M.,dkk. 2017. Sabun Cair "Granat Putih" (Punica Granatum) Sebagai Obat Keputihan. Universitas Muhammadiyah Magelang

Hardiningtyas, S. D. 2009. Aktivitas Antibakteri Ekstrak Karang Lunak Sarcophyton Sp. Yang Difragmentasi dan Tidak Difragmentasi di Perairan Pulau Pramuka, Kepulauan Seribu. Skripsi. Institut Pertanian: Bogor.

Idadi, 2013 dalam L.G.E, Windsrini., Astuti, K. W., N.K., Warditiani. Skrining Fitokimia Ekstrak Metanol Kulit Buah Manggis (Garcinia mangostana L.). Universitas Udayana: Bali

Indah, 2011., Dalam Suryandri Dyah Fitri dan Zulfa Rufaida. 2013. Hubungan pemakaian sabun pembersih 
kewanitaan dengan terjadinya keputihan pada wanita usia subur (WUS) didesa karang jeruk kecamatan jatirejo kabupaten mojokerto. Politeknik Kesehatan Majapahit.

Ismaini, L. 2011. Aktivitas Antifungi Ekstrak (Centella asiatica (L.) Urban terhadap Fungi Patogen pada Daun Anggrek (Bulbophyllum flavidiflorum Carr.). Jurnal Penelitian Sains, 4 (1): 47-50.

Jusnita, nina., Riska arguer syah. 2017. Formulasi dan Uji Stabilitas Fisik Sediaan Shampo Dari Ekstrak Etanol Daun Pare (Momordica charantia Linn.). Fakultas Farmasi Universitas 17 Agustus 1945: Jakarta

Katzung, bertram G., Susan B. Masters, Anthony J. Trevor. 2013. Farmakologi dasar dan klinik edisi bahasa indonesia, Ricky Soeharsono edisi 12. EGC: Jakarta

Kusuma Irawan W., Edi Sukaton dan Yongung Kim. 2009. Antifungal Activity and Phytochemical Study of Selected Medicinal Plants in East Kalimantan. Departemen Farmasi Herbal Rekayasa, College of Herbal Bio-industri, Daegu Haany University, Gyeongsangbuk-do: Korea Selatan

Lusiana, kesi., Hartati soetjipto dan Dewi K.A.K. Hastuti. 2013. Aktivitas Antibakteri dan Kandungan Fitokimia Ekstrak Daun Waru Lengis (Hibiscus tiliaceus L.) Sebagai Bahan Dasar Pembuatan Sampo

Marhaeni, Gusti Ayu. 2016. Keputihan Pada Wanita. Politeknik Kesehatan Denpasar: Bali

Marini, dkk., 2016. Hubungan Kandungan Hara Tana dengan Produksi Senyawa Metabolit Sekunder Pada Tanaman Duku (Lansium domesticum Cor var Duku) dan Potensinya Sebagai Larvasida. Sumatera Selatan

Meisarani, Agi., dan Rahmadhania Mega Zelika. 2016. Kandungan Senyawa Kimia dan Bioaktivtas. Universitas Padjadjaran: Bandung

Mutmainah dan Yuvianti Dwi Prayanto. Formulasi dan evaluasi sabun cair ekstrak etanol jahe merah (Zingiber officinale var Rubrum) serta uji aktivitasnya sebagai antikeputihan. Fakultas farmasi sekolah tinggi ilmu farmasi Yayasan Pharmasi: Semarang

Putri, Z.F. 2010. Uji Aktivitas Antibakteri Ekstrak Etanol Daun Sirih (Piper betle L.) terhadap Propionibacterium acne dan Staphylococcus aureus multiresisten. Skripsi. Fakultas Farmasi Universitas Muhammadiyah: Surakarta

Rahmi,dkk. 2017. Formulasi Sabun Pembersih Kewanitaan (Feminime Hygiene) dari Ekstrak Kulit Buah Durian (Durio zibethinus Murray). Akademi Farmasi Bina Husada Kendari, STIKES Mandala Waluya Kendari

Saleh, A., Yuliastri, W. O., Isrul, M., Pusmarani, J., Juliansyah, R., \& Dewi, C. (2020). Ethnomedicinal Study of Medicinal Plants used against Infectious Disease by Muna Tribe of South-East Sulawesi, Indonesia. Research Journal of Pharmacy and Technology, 13(4), 1829-1834.

Supartono, dkk. 2016. Uji Antibakteri Ekstrak Daun waru (Hibiscus tiliaceus L.) Terhadap Staphylococcus aureus, Staphylococcus epidermidis dan Penapisan Kandungan Kimia. Institut Sains dan Teknologi Nasional: Bogor.

Wahyuningtyas, E. 2008. Pengaruh Ekstrak Graptophyllum pictum terhadap Pertumbuhan Candida albicans pada Plat Gigi Tiruan Resin Akrilik. Indonesian Journal of Dentistry, 15 (3):187191. 